\title{
Integration Geo-informatics Technology Application and Geostatistical Analysis for Groundwater Potential Zones Assessment: A Case Study of Chon Buri Province, Thailand
}

\author{
PICHITPORN PHOLGERDDEE \\ Faculty of Geoinformatics \\ Burapha University \\ 169 LonghaadBangsaen Road, Saensook, Mueang, Chon Buri province, 20131 \\ THAILAND
}

\begin{abstract}
This study explores the groundwater sources in Chon Buri province using Geospatial Technology and spatial analysis in order to assess the groundwater potential for the province. The findings reveal that there are 431 artesian wells out of 651 registered wells for the study. The average specific water volume of artesian wells is in the range of $0.054-3.415$ cubic meters and hour meters in Na Matoom Subdistrict, PanatNikom District where there is the highest specific water content found. Also, it indicates that the independent variables are able to explain the variation of the dependent variable, the specific amount of water, in which the decision coefficient is of 0.949 or 94.90 percent. The model has a high level of decision coefficient (approaching 1 or $100 \%$ ) with $94.90 \%$ accuracy and can be used to describe the specific water content of artesian wells in Chon Buri province. In addition, the model can be used to assess the groundwater potential in the province and widely applied to other areas of the milieu alike.
\end{abstract}

Key-Words: -Geo-informatics technology, Geostatistical Analysis, Groundwater Potential, Specific Capacity Received: June 6, 2020. Revised: December 23, 2020. Accepted: January 2, 2021. Published: February 2, 2021.

\section{Introduction}

Water is essential for life. Without water, living things cannot survive. Yet, it is the fundamental factor in terms of economy. Due to the increasing population and economic growth in all areas of the world, this results in a greater demand for water and water shortage problems. Thus, water management is very important in order to maintain sufficient water resources for living. Groundwater is an important source of water for consumption, and it is a reserve water source that can be used in case of surface water shortage. The water shortage problem can occur for both surface water and groundwater. However, groundwater is a good alternative source of water for a wide range of activities. A quantitative assessment of the potential of groundwater is, therefore, interesting for use in management, including solving the problem of improper use of groundwater. Usually, groundwater is a natural resource that is circulated according to the water cycle, but if the plan or the development of groundwater is used incorrectly according to academic principles, it may cause other effects. A decrease in the level of groundwater resulted in the subsidence of the soil layer saltwater inflow, for instance [1]. As a result, the government has issued the Groundwater Act, B.E. 2520 for the proper use of groundwater [2].

Chon Buri is the province with the best economy in the eastern region of Thailand. It is one of the provinces being developed rapidly in terms of economy, society, industrial growth, especially tourism. There are well-known tourist attractions for both Thais and foreigners. This resulted in the rising population in the area and the expansion of the city affecting the demand for water consumption. Such problems have increased the use of water, and the existing water service sources may not be sufficient to meet the water needs in each area, especially in the tourist season. Moreover, Chon Buri is a province without a river to flow through, but there are only short streams and canals. Reservoir is built to store water, but it cannot thorough water service because it is used only for industrial and agricultural purposes. Therefore, residences or businesses built around the beach, such as hotels and bungalows, do not have enough water for consumption while tab water supply is available. As the community expanded and increased tourism promotion, the problem of water shortage has also increased, especially in seaside tourism.

In terms of the importance, Groundwater accounts for $30 \%$ of all fresh water worldwide which is the main source of water for the entire world population. When there is a drought, in an international principle, groundwater is considered the most important resource that can be used to mitigate drought, while the surface water is insufficient. This research focuses on assessing the potential of groundwater resources in Chon Buri 
Province using Geospatial Technology in conjunction with spatial and statistical analyses with multiple regression analysis in order to investigate the relationship between the spatial variables and the specific water volume of the wells as well as to create a model for assessing groundwater potential in the province. Thus, the model can also be generalized to the similar context globally.

\section{Literature Review}

Groundwater refers to the part of the subsurface water in the saturated zone, including groundwater stream. It is found underground in the cracks and spaces in soil, sand and rock, where it is stored in and moves slowly through geologic formations of soil, sand and rocks called aquifers [3].

Geographic Information System (GIS) is a system applied to the collection of geographic or physical information with a lot of information systematically. It can be used to analyze and present the information very quickly. In hydro geological study, it always contains a large amount of information such as 20-50 monitoring wells or observation wells. Each well contains the information related to each other, such as geological features, Geometrics data and multiple sets of groundwater quality data collected at different times. In addition, the area investigated contains a large amount of information such as Topography, Meteorology, Hydrology, soil characteristics and types of land and road use, etc. It is, therefore, difficult to systematically store the data for analysis, interpretation and presentation. Hence, a GIS has been developed to store, analyze and present the data in different levels or layers and characteristics of current maps with computer programs. These can be used for applications such as ArcInfo, Arcview MapInfo and ArcGIS. The data collected can also be presented in an informative manner for individual wells, such as ground water levels, rock hierarchy, soil layer, water quality in the area or area of each artesian well and potential of underground water source [2]. According to the study by [4], GIS was applied to spatial analysis for the feasibility of developing groundwater sources for human consumption in Phra Thong Kham District, Nakhon Ratchasima Province. It indicated that the appropriateness of groundwater development was divided into 4 levels, namely, very suitable, moderate, little and unsuitable. There was only $9.64 \%$ for suitable villages to develop groundwater for them, $28.43 \%$ moderate, $54.13 \%$ less suitable, and $7.78 \%$ unsuitable. Most areas were suitable for low and medium groundwater development due to the quality of salty groundwater. Therefore, it was not suitable for the development of groundwater sources even there was a study of the watershed potential for mapping using GIS with remote sensing to determine the agricultural potential of the Musi Basin. Groundwater maps have been improved over the years due to the increased demand for water. In addition, there are a lot of factors in studying groundwater as mentioned above. Therefore, for the demarcation of the groundwater potential by applying GIS models, it is a simple and easy way to improve the data for mapping groundwater potential [5] The application of GIS in Korea was widely used too. [6] mapped GIS to divide groundwater potential, analyzing the specific water content of each well, Specific Capacity (SPC) with hydrological factors and assessed the susceptibility of each factor in mapping groundwater potential using GIS. It was found that the soil surface affected the groundwater potential more than the ground level, and the mapping data could be used for groundwater management and groundwater exploration. The domestic application of Geographic Information System (GIS) model was widely used, especially for large organizations or various research works to assess the situations such as earthquakes, landslides and floods, as well as using GIS to assess pesticide pollution potential in the central Thailand. [7] examined the soil type, slope, land use, depth of groundwater wells and rainfall, in which these factors might influence the contamination of chemicals in Kanchanaburi, Ratchaburi and Suphanburi provinces. The results showed that the depth was found most significant between groundwater contamination, and agricultural areas in the central region of Thailand generally when surface-treated soils without adding up to deep aquifers. If these characteristics were reduced, the threat of pesticide contamination was also reduced. In addition, drilling for groundwater sources is important in the application of GIS to save budget and reduce working time. [8] studied the number and distribution of artesian wells as well as the relationship between the number of artesian wells with economic data, society and physical characteristics of groundwater to be able to identify rural areas that still lacked water. This kind of study can be used as a guideline for budget allocation in accordance with the target. The study revealed that there were artesian wells in rural areas of Thailand provided by the government. There were 70 percent of villages with adequate water supply and 30 percent of the area where there was a shortage of potable water, separated by villages with the potential to penetrate groundwater wells, and 70 percent no drilling potential of artesian wells. 
However, there were $25 \%$ of surface water sources, no groundwater well drilling potential and $4 \%$ of surface water sources allowing data to be analyzed and distributed further.

\section{Findings}

Factors used in the analysis of groundwater potential are as follows:

1. Specific water content of the groundwater wells which indicate the groundwater production capacity of each well. [2] suggested to calculate the amount of pumping water (Pumping Rate: Q) divided by the reduction in the pumped well [13]. (Tootle Drawdown in Well: $S_{w}$ )

$$
\text { Specific Capacity }=\mathrm{Q} / \mathrm{S}_{\mathrm{w}}
$$

by using the data of specific artesian well with a specified rating and the amount of water pumped out and the reduction of the water range of 431 wells from the total number of registered artesian wells of 651 wells to calculate the specific water volume. As shown in Table 1 and figure 1, there are wells with high specific water content which demonstrate high capacity or potential for groundwater utilization.

Table1 Average SPC divided by Sub-districts of Chon Buri Province

\begin{tabular}{|c|l|c|c|}
\hline District & \multicolumn{1}{|c|}{ Sub-district } & $\begin{array}{c}\text { Average } \\
\text { SPC } \\
\text { (cubic } \\
\text { meter / } \\
\text { hour / } \\
\text { meter) }\end{array}$ & $\begin{array}{c}\text { Number } \\
\text { of } \\
\text { artesian } \\
\text { wells }\end{array}$ \\
\hline Koh Chan & -Khoh Chan & 0.354 & 22 \\
& -Tesaban Tambol & 0.247 & 3 \\
& ThaBoonmee & 0.290 & 10 \\
& -ThaBoonmee & 0.223 & 16 \\
\hline Bo Thong & -Bor Thong & 0.061 & 4 \\
& -KasetSuwan & 0.093 & 1 \\
& -Bor Kwang Thong & 0.454 & 17 \\
& -Wat Suwan & 0.288 & 7 \\
& -That-thong & 0.072 & 4 \\
\hline
\end{tabular}

Table 1 Average SPC divided by Sub-districts of Chon Buri Province (Continued)

\begin{tabular}{|c|c|c|c|}
\hline District & Sub-district & $\begin{array}{c}\text { Averag } \\
\text { e SPC } \\
\text { (cubic } \\
\text { meter / } \\
\text { hour / } \\
\text { meter) }\end{array}$ & $\begin{array}{l}\text { Number } \\
\text { of } \\
\text { artesian } \\
\text { wells }\end{array}$ \\
\hline Banglamung & $\begin{array}{l}\text {-Banglamoong } \\
\text {-Nong Plalai } \\
\text {-HuayYai } \\
\text {-TambolHuayYai } \\
\text {-Na Klue } \\
\text {-Pong } \\
\text {-Takian Tia } \\
\text {-Nong Prue } \\
\text {-Khao Maikhaew }\end{array}$ & $\begin{array}{l}0.076 \\
0.181 \\
0.327 \\
0.142 \\
0.237 \\
0.123 \\
0.210 \\
0.082 \\
0.310\end{array}$ & $\begin{array}{c}2 \\
23 \\
6 \\
1 \\
3 \\
11 \\
6 \\
6 \\
2\end{array}$ \\
\hline Ban Bueng & $\begin{array}{l}\text {-TesabanMueng } \\
\text { Ban Bueng } \\
\text {-Nong Saak } \\
\text {-Ban Bueng } \\
\text {-Nong Sam Sak } \\
\text {-MaabPhai } \\
\text {-Nong Pai Kheaw } \\
\text {-Nongbondeang } \\
\text {-Klongkew } \\
\text {-Nong-I roon }\end{array}$ & $\begin{array}{l}0.126 \\
0.215 \\
0.194 \\
0.082 \\
0.167 \\
0.290 \\
0.293 \\
0.214 \\
0.292\end{array}$ & $\begin{array}{c}1 \\
\\
6 \\
7 \\
2 \\
6 \\
11 \\
8 \\
6 \\
15\end{array}$ \\
\hline PhanatNikom & $\begin{array}{l}\text {-Mon Nang } \\
\text {-Sara Siliam } \\
\text {-PanatNikom } \\
\text {-Na Matoom } \\
\text {-Nong Kayad } \\
\text {-Nang Prue } \\
\text {-Nong Hiang } \\
\text {-Ban Chang } \\
\text {-Na Rerk } \\
\text {-Hua Tanoon } \\
\text {-Na Wanghin } \\
\text {-KoodNgoong } \\
\text {-Toong Kwang }\end{array}$ & $\begin{array}{l}0.373 \\
0.076 \\
0.500 \\
3.415 \\
0.072 \\
0.314 \\
0.314 \\
0.159 \\
0.260 \\
0.130 \\
0.223 \\
0.200 \\
0.200\end{array}$ & $\begin{array}{c}9 \\
10 \\
1 \\
3 \\
3 \\
19 \\
19 \\
4 \\
13 \\
6 \\
8 \\
1 \\
1\end{array}$ \\
\hline Phan Thong & $\begin{array}{l}\text {-Nong Hong } \\
\text {-Maab Pong } \\
\text {-Nong Tamlueng }\end{array}$ & $\begin{array}{l}0.419 \\
0.267 \\
0.136\end{array}$ & $\begin{array}{l}6 \\
2 \\
3\end{array}$ \\
\hline $\begin{array}{l}\text { Muang } \\
\text { Chonburi }\end{array}$ & $\begin{array}{l}\text {-Samnakbok } \\
\text {-Nong Mai Daeng } \\
\text {-Nong Kang Kok } \\
\text {-Huay Kapi } \\
\text {-Mueng } \\
\text {-Napa } \\
\text {-Nong Ree } \\
\text {-Tesaban Tambol } \\
\text { Sila }\end{array}$ & $\begin{array}{l}1.768 \\
0.083 \\
0.114 \\
0.151 \\
0.277 \\
0.115 \\
0.132 \\
0.106\end{array}$ & $\begin{array}{l}2 \\
1 \\
3 \\
4 \\
1 \\
1 \\
3 \\
2\end{array}$ \\
\hline
\end{tabular}


Table 1 Average SPC divided by Sub-districts of Chonburi Province (Continued)

\begin{tabular}{|c|l|c|c|}
\hline District & \multicolumn{1}{|c|}{ Sub-district } & $\begin{array}{c}\text { Average } \\
\text { SPC } \\
\text { (cubic } \\
\text { meter / } \\
\text { hour / } \\
\text { meter) }\end{array}$ & $\begin{array}{c}\text { Number } \\
\text { of } \\
\text { artesian } \\
\text { wells }\end{array}$ \\
& & 0.068 & \\
\hline Sri Racha & -Khao Kansong & 0.122 & 4 \\
& -Bang Pra & 0.216 & 1 \\
& -Bor Win & 0.174 & 13 \\
& -Bueng & 0.054 & 1 \\
& -Nong Kam & 0.075 & 1 \\
& -Surasak & 0.153 & 1 \\
& -ToongSukla & 0.461 & 2 \\
\hline -Laem Chabang & 1.743 & 26 \\
& -SataHeeb & 0.617 & 15 \\
& -TesabanTambolKled & 0.470 & 3 \\
& -Khaew & 0.927 & 21 \\
& -Bang Saray & 0.310 & 8 \\
& -Plutaluang & - & - \\
\hline Total & -Na Chomtian & & $\mathbf{4 3 1}$ \\
\hline
\end{tabular}

Table 1 shows the average specific water volume of the sub-district wells in all 11 districts of Chon Buri Province. It was found that the highest average was 3.415 cubic meters / hour / meter located in $\mathrm{Na}$ Matoom district PanatNikom district is in the east of Chonburi Province. The district is characterized by undulating plains and hills in aquifers, sediments, and foothills. The reason for the higher average water content than other areas is due to the topography and soil that retains the water well due to the deposition and accumulation of various sediments. Rubble, gravel, sand, decay or eroded soil are leached out of the original rock by its natural culprits, such as glaciers, wind, glaciers, or sea waves, depositing and solidifying in the accumulation basin. The lowest mean is 0.054 cubic meter / hour / meter found in Nong Kam Subdistrict, Sriracha district where it is in the east of Chon Buri Province. They are characterized by flat, undulating areas and hills, artesian wells, mostly in granite aquifers because they are non-hollow rocks, hard, durable, dense, inelastic, and do not absorb water and moisture, thus, allowing less water retention.

\section{Average annual rainfall of 10 years}

The results of the 10-year average rainfall study (2008-2018) by Meteorological Department in figure 2, were the precursor water that could be a water source for groundwater based on the study of [9]. In analysis, the researcher used the average rainfall data from the rainfall measuring station in Chon Buri province and all 5 measuring stations nearby: Chon Buri Station, Koh Si Chang Station,
Pattaya Station, Sataheep Station and Haeng Bang Station using statistical data (10 years) and spatial interpolation with Kriging method. The average annual rainfall for 10 years was found in the range of 89.62-117.59 cubic meters per year as shown in figure 2. Most of the rainfall found was distributed throughout the province of Chon Buri with the area that has the most rainfall, covering the lower part of Chon Buri Province or Sataheep Subdistrict, Municipality, KledKaew Subdistrict, Bang Saray Sub-District, Plutaluang, and $\mathrm{Na}$ Chomtian Subdistrict. The areas with low rainfall were found in the southwest area of Banglamung Subdistrict, Nong Plalai Subdistrict, HuayYai Subdistrict, Na Klue Subdistrict, Pong Subdistrict, Takian Tia Subdistrict, Nong Prue Subdistrict, and Khao Maikhaew Subdistrict.

\section{10-year average evaporation volume}

The results of the 10-year evaporation volume study (2008-2018) in figure 3 are based on the study of [9] who applied a calculation of spatial interpolation using Kriging method. [10] explained that evaporation volume is the rain water that falls to the earth's surface and will return to the atmosphere in the form of water vapor through evaporation. Evaporation is due to the calculation of the precipitation, runoff in the accumulated soils, together to determine the evaporation value. The evaporation rate depends on the nature of the evaporated surface. The evaporation rate from the water-saturated soil is approximately equal to the evaporation rate from the neighboring surface at the same temperature as shown in figure 3 . It was found that the evaporation volume of Chon Buri province was in the range $19.00-120.87$ cubic meters.

\section{Digital Elevation Model: DEM}

As a result, the study of the Digital Elevation Model with a strategic detail of 30 micrometers from ASTER Global Digital Elevation Map GIDEM, DEM in figure 4 indicates the water filling area and the rate of penetration into the groundwater of surface water or rainwater, where the low slope or flat area has a greater chance of water to seep into the soil layer below at the mountains and the high altitudes. As the slope grows, it changes from an additional area, the water becomes the rainwater receiving function to disperse and flow as it pushes the streams into the main waterway in the form of surface water. The direction of the flow of groundwater that must flow from the higher to the lower [12] and the Digital Elevation Model (DEM) is used to show the seepage of water into the underground in the low slope area, affecting the high groundwater potential in the area 
with high slope. It has a low groundwater potential, similar to a slope. It was found that the altitude of Chon Buri Province is in the total of 801 micrometers as illustrated in Figure 4. The highaltitude area is in the high mountain terrain in Muang Sri Racha, Ban Bueng, Nong Yai and Bro Thong districts. In addition, it is a common flat area in Chon Buri province.

\section{The characteristics of aquifers}

Figure 5 indicating the Geological map where Aquifer is a porous rock layer that can hold water and flow through porosity for use [11]. In Chon Buri, there are 10 types of aquifers, mostly in hard rock formations with a percentage of the area of aquifers as shown in table 2.

Table 2 Percentage of the area of aquifers

\begin{tabular}{|l|c|c|}
\hline \multicolumn{1}{|c|}{ Aquifers } & $\begin{array}{c}\text { Area } \\
\text { (square } \\
\text { kilometers) }\end{array}$ & $\begin{array}{c}\text { Percent per } \\
\text { area }\end{array}$ \\
\hline Granite (Cgr) & $1,529.942$ & 7.96 \\
\hline Sandstone (Ck1) & $1,068.950$ & 5.56 \\
\hline Limestone (O) & 185.622 & 0.97 \\
\hline Shale (P) & 265.333 & 1.38 \\
\hline $\begin{array}{l}\text { Nile stone } \\
\text { (PEsch) }\end{array}$ & 226.148 & 1.18 \\
\hline $\begin{array}{l}\text { Stone Cheese } \\
\text { (PEsch) }\end{array}$ & 408.988 & 2.13 \\
\hline $\begin{array}{l}\text { Andesite Stone } \\
\text { (Post Cv) }\end{array}$ & 46.683 & 0.24 \\
\hline $\begin{array}{l}\text { Sand gravel } \\
\text { sediment (Qa) }\end{array}$ & $7,048.100$ & 36.65 \\
\hline $\begin{array}{l}\text { Sediment and } \\
\text { gravel (Qt) }\end{array}$ & $7,844.469$ & 40.80 \\
\hline $\begin{array}{l}\text { Quartite Stone } \\
\text { (SD) }\end{array}$ & 603.986 & 3.14 \\
\hline Total & $\mathbf{1 9 , 2 2 8 . 2 2 1}$ & $\mathbf{1 0 0}$ \\
\hline
\end{tabular}

The aquifers of sediment and gravel (Qt) are the most abundant rocks in Chon Buri province, representing 40.80 percent per area. As shown in Figure 5, they are spread over all areas caused by the accumulation of sediments such as gravel, sand, silt and clay, which are the ancient sediments of the Chao Phraya lowlands. Some of the sediments of this old age lie beneath the floodplains that are 50150 meters younger than the depths of the groundwater. The water supply capacity ranges from $10-100 \mathrm{~m}^{3} / \mathrm{h}$. This type of water layer refers to the groundwater layer developed from the marl layer.

The least existing aquifer in Chon Buri Province is the Persian Aged Cabonet, accounted for 0.97 percent as shown in Figure 5. It is located in the south, consisting of gray limestone with black shirt, gray shale sandstone and gray and white rounded pebble stone with reddish brown. The depth of the groundwater layer is approximately 20-40 meters, the water capacity ranges from $1-40 \mathrm{~m}^{3} / \mathrm{h}$.

\section{Slope}

The results of the slope study from DEM in figure 6 calculated as the degree of the slope. If there is a steep slope in any area, it may result in runoff of surface water and make the soil seepage rate low, and the amount of water added to the groundwater is less or vice versa. If any area has a very slope, it is more likely that rainwater seeps through the soil and replenishes it into the groundwater [12]. As illustrated in Figure 6, the slope of Chon Buri Province is very high in the mountainous terrain found in Muang Sri Racha, Ban Bueng, Nong Yai and Bor Thong districts. In addition, it is a common flat area throughout the province.

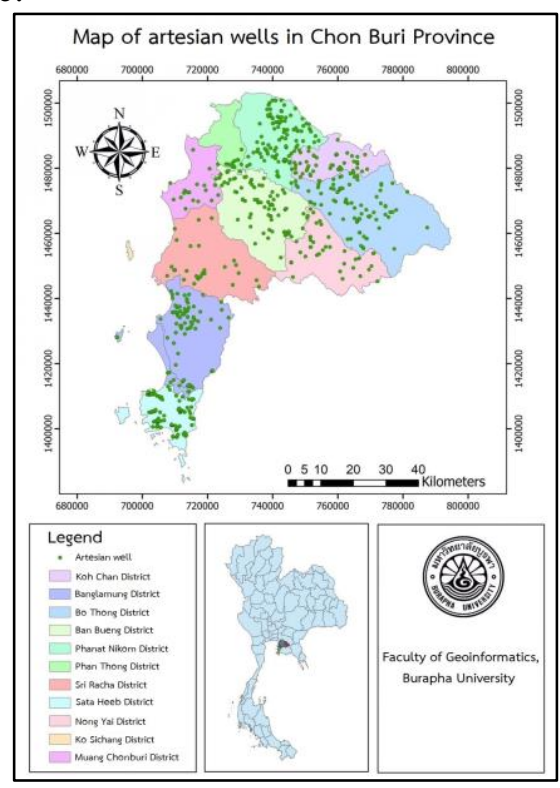

Figure 1: Map of artesian wells in Chon Buri Province

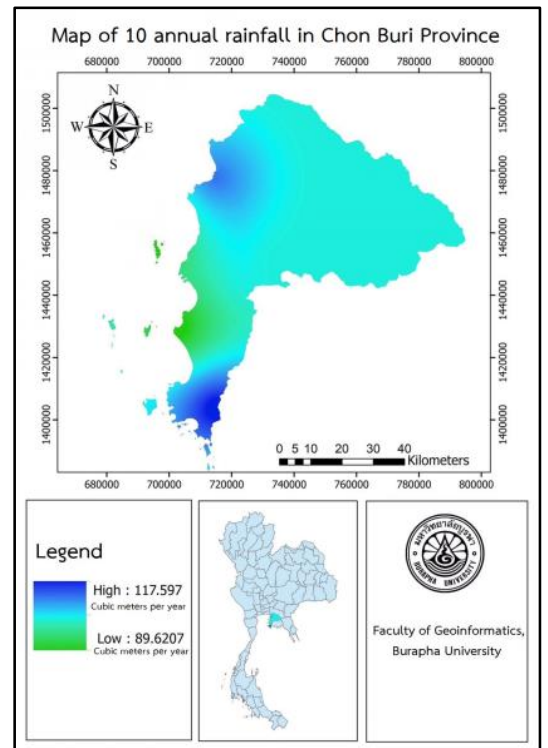

Figure 2: Map of 10 annual rainfall in Chon Buri Province 


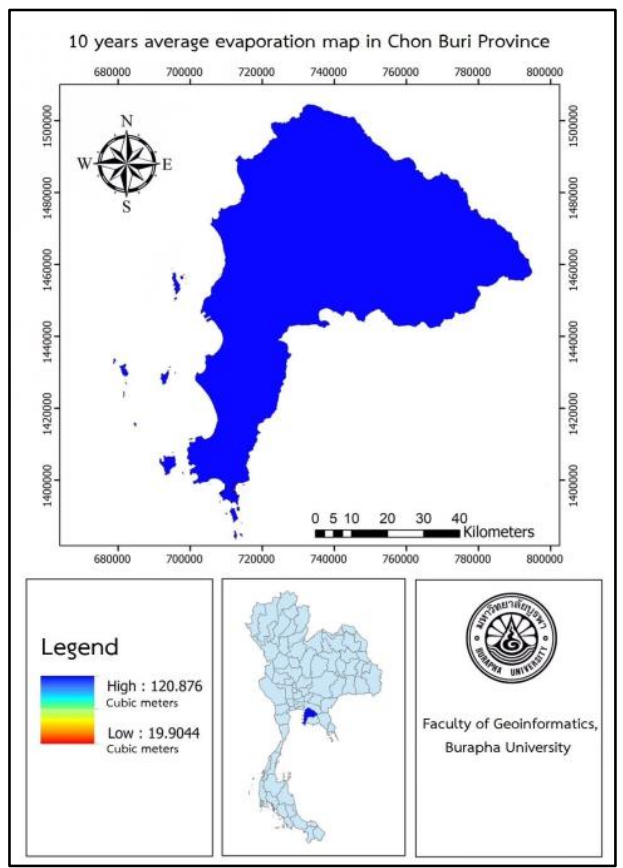

Figure 3: 10-year average evaporation map in Chon Buri Province

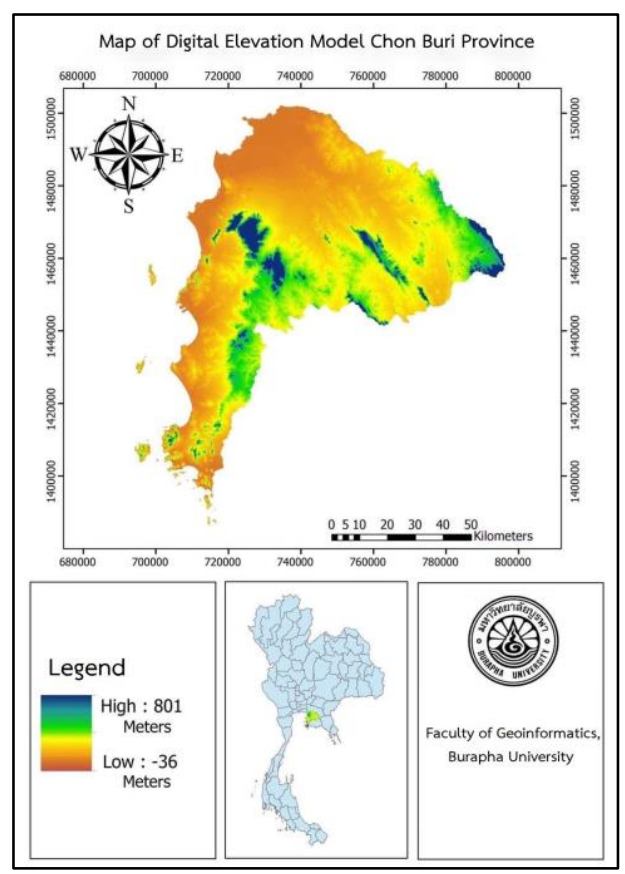

Figure 4: Map of Digital Elevation Model in Chon Buri Province

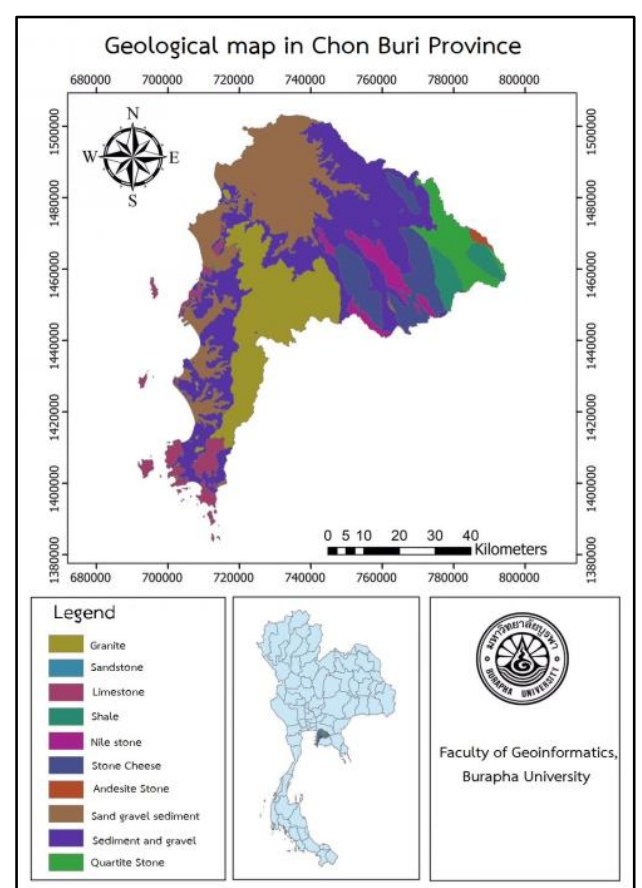

Figure 5: Geological map in Chon Buri Province

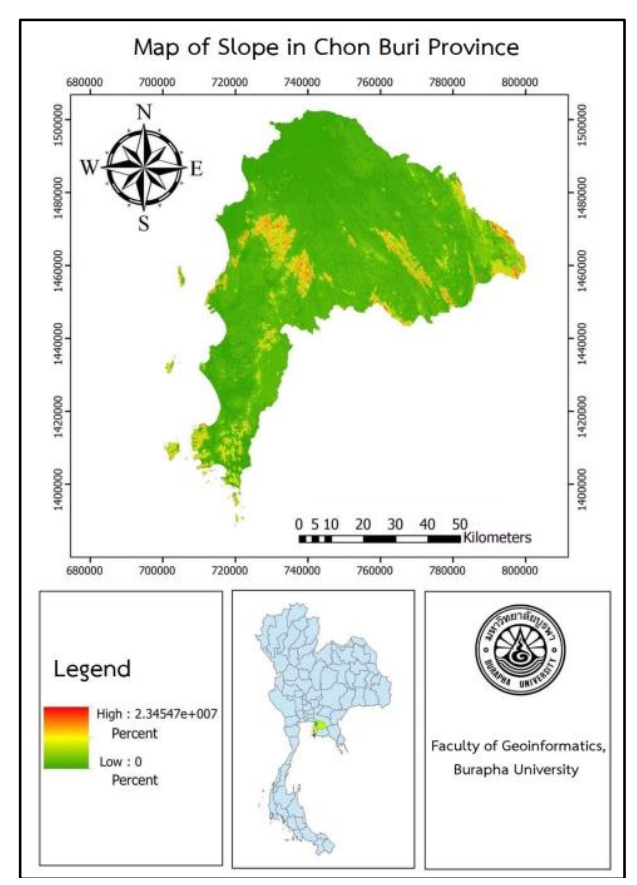

Figure 6: Map of Slope in Chon Buri Province 


\section{Geostatistical Analysis for Groundwater Potential Zones Assessment}

From the Correlation Analysis between the specific water volumes of 431 artesian wells (SPC) together with the 5 spatial factors as shown in Table 3 , it was found that the specific water content of the wells do not correlate with the 5 spatial factors: 10year average rainfall, 10-year average evaporation, geology, DEM and slope. There is only the 10-year average evaporation, a spatial factor, correlated with DEM with a correlation coefficient of -0.971 , and this relationship is statistically significant at the level of 0.01 .

Table 3 Results of the relationship between the Pearson Correlation models

\begin{tabular}{|c|c|c|c|c|c|c|c|}
\hline \multicolumn{8}{|c|}{ Correlations } \\
\hline \multicolumn{2}{|c|}{ Variables } & \multirow{3}{*}{\begin{tabular}{|l|}
$\begin{array}{l}\text { Specific } \\
\text { amount of } \\
\text { water }\end{array}$ \\
1
\end{tabular}} & \multirow{3}{*}{$\begin{array}{l}\text { Average } \\
\text { rainfall }\end{array}$} & \multirow{3}{*}{$\begin{array}{l}\text { Annual } \\
\text { average } \\
\text { evapora- } \\
\text { tion }\end{array}$} & \multirow{3}{*}{ DEM } & \multirow{3}{*}{ Geology } & \multirow{3}{*}{ Slope } \\
\hline \multirow{4}{*}{\begin{tabular}{|l|} 
Specific \\
amount of \\
water
\end{tabular}} & & & & & & & \\
\hline & $\begin{array}{l}\text { Pearson } \\
\text { Correlation }\end{array}$ & & & & & & \\
\hline & Sig. (2-tailed) & & & & & & \\
\hline & $\mathrm{N}$ & 449 & & & & & \\
\hline \multirow{3}{*}{$\begin{array}{l}10 \text {-year } \\
\text { average } \\
\text { rainfall }\end{array}$} & $\begin{array}{l}\text { Pearson } \\
\text { Correlation } \\
\end{array}$ & -.304 & 1 & & & & \\
\hline & Sig. (2-tailed) & .085 & & & & & \\
\hline & $\mathrm{N}$ & 33 & 54 & 23 & & & \\
\hline \multirow{3}{*}{\begin{tabular}{|l|}
10 -year \\
average \\
evapora- \\
tion
\end{tabular}} & $\begin{array}{l}\text { Pearson } \\
\text { Correlation }\end{array}$ & -.281 & .263 & 1 & & & \\
\hline & Sig. (2-tailed) & .275 & .224 & & & & \\
\hline & $\mathrm{N}$ & 17 & 23 & 23 & 23 & & \\
\hline \multirow[t]{3}{*}{ DEM } & $\begin{array}{l}\text { Pearson } \\
\text { Correlation }\end{array}$ & -.067 & .116 & $-.971^{* *}$ & 1 & & \\
\hline & Sig. (2-tailed) & .158 & .404 & .000 & & & \\
\hline & $\mathrm{N}$ & 449 & 54 & 23 & 833 & & \\
\hline \multirow[t]{3}{*}{ Geology } & $\begin{array}{l}\text { Pearson } \\
\text { Correlation }\end{array}$ & -.004 & -.060 & .210 & -.064 & 1 & \\
\hline & Sig. (2-tailed) & .976 & .669 & .336 & .532 & & \\
\hline & $\mathrm{N}$ & 57 & 54 & 23 & 99 & 99 & 25 \\
\hline \multirow[t]{3}{*}{ Slope } & $\begin{array}{l}\text { Pearson } \\
\text { Correlation }\end{array}$ & .361 & .023 & -.019 & -.171 & .295 & 1 \\
\hline & Sig. (2-tailed) & .186 & .915 & .947 & .415 & .152 & \\
\hline & $\mathrm{N}$ & 15 & 25 & 14 & 25 & 25 & 25 \\
\hline
\end{tabular}

Then, the five factors, including 10-year average rainfall, 10-year average evaporation, geology and slope were analyzed using the multiple linear regressions in order to create a model for estimating the specific water content of the artesian wells. The independent variables are slope, average rainfall, average evaporation per year, geology, numerical height, whereas the dependent variable is specific water volume.
Table 4 Variables table

\begin{tabular}{|c|l|c|c|}
\hline \multicolumn{3}{|c|}{ Variables Entered/Removed $^{\text {a }}$} \\
\hline Model & Variables Entered & $\begin{array}{l}\text { Variables } \\
\text { Removed }\end{array}$ & Method \\
\hline 1 & $\begin{array}{l}\text { Slope, Average } \\
\text { rainfall, average } \\
\text { evaporation per year, } \\
\text { geology, DEM }\end{array}$ & & Enter \\
\hline
\end{tabular}

Table 4 indicates the slope factor, average rainfall, 10-year average evaporation, geology and DEM are variables that relate to the specific amount of water entering the equation.

Table 5 Model Summary table

\begin{tabular}{|c|c|c|c|c|}
\hline \multicolumn{7}{|c|}{ Model Summary } \\
\hline Model & R & R Square & Adjusted R Square & $\begin{array}{c}\text { Std. Error of the } \\
\text { Estimate }\end{array}$ \\
\hline 1 & $.974^{\mathrm{a}}$ & .949 & .865 & .07766 \\
\hline $\begin{array}{l}\text { a. Predictors: (Constant), Slope, average rainfall, average evaporation per year, } \\
\text { geology and numerical height }\end{array}$ \\
\hline
\end{tabular}

The data analysis in table 5 showed that the independent variables: slope factor, average rainfall, average annual evaporation, geology and numerical height model are related to the variation of the dependent variables. The specific water content of the well is 0.949 or $94.9 \%$. The decision coefficient is high (approaching 1 or $100 \%$ ), which makes the model accurate to $94.9 \%$, so it can be used to describe the specific water content of artesian wells in Chon Buri province.

Table 6 ANOVA Table

\begin{tabular}{|c|c|c|c|c|c|c|}
\hline \multicolumn{7}{|c|}{ ANOVA $^{\mathbf{a}}$} \\
\hline \multirow{2}{*}{ Model } & $\begin{array}{c}\text { Sum of } \\
\text { Squares }\end{array}$ & df & $\begin{array}{c}\text { Mean } \\
\text { Square }\end{array}$ & F & Sig. \\
\hline \multirow{2}{*}{1} & Regression & .338 & 5 & .068 & 11.209 & $.037^{\mathrm{b}}$ \\
\cline { 2 - 8 } & Residual & .018 & 3 & .006 & & \\
\cline { 2 - 8 } & Total & .356 & 8 & & & \\
\hline
\end{tabular}

a. Dependent Variable: Specific amount of water

b. Predictors: (Constant), Slope, average rainfall, Average evaporation per year, Geology and DEM

ANOVA Table in table 6 is an analysis of variance. It is concluded that slope, average rainfall, average evaporation per year, geology, numerical height is linearly related to specific water content because the significant value is $0.037>0.05$

\section{Conclusion}

In this study, the researcher obtained the data from the Department of Groundwater Resources, Chon Buri Province, to calculate the 
specific water content of the artesian wells indicating the specific capacity to provide groundwater of each well. This is only one method used to assess groundwater potential. The spatial factors affecting the assessment of groundwater potential of Chon Buri Province are rainfall, volatilization, geology, DEM and slope. All factors were analyzed for relationships with the specific water content of the artesian wells, using to create a model to assess the groundwater potential of the entire Chon Buri province.

In this study, the data of specific artesian wells were used to determine the accuracy of 431 wells from the total of 651 wells. The average specific water volume of artesian wells in Chon Buri province ranges from $0.054-3.415$ cubic meters. It was found that the area in Namatum subdistrict PhanatNikhom District contained the highest specific water volume. It is located in the east of Chon Buri Province, characterized by undulating plains and hills in the aquifers, sediment, gravel (Qa) and gravel sediment (Qt) due to its topography and sedimentary rocks. It is a rocky stratum that holds water well, formed by swirling over it and solidifying into the rock in the accumulated basins.

Meanwhile, Nong Kham Subdistrict, Sriracha District, has the lowest specific water volume, where it is located in the east of Chon Buri Province, characterized by flat, undulating areas and hills. Most artesian wells are in granite aquifers as they are non-hollow, hard, durable, dense, and inelastic, they do not absorb water and moisture, they retain less water than other areas.

The researcher applied geospatial technology with geo-statistics and Correlation analysis to analyze the specific water content of 431 artesian wells (SPC) together with the 5 spatial factors to create a model for assessing groundwater potential in Chon Buri Province. The study showed that the slope factor, average rainfall, average annual evaporation, geology and DEM are variables that correlate with specific water content. The researcher then determined the independent variables as five spatial factors: slope factor, average rainfall, average annual evaporation, geology and DEM. These variables are related to the variation of the dependent variable in which the specific water volume variables have a decision coefficient equal to 0.949 or 94.9 percent. Thus, the model has a high decision coefficient (approaching 1 or $100 \%$ ), which gives the model $94.9 \%$ accuracy, so it can be used to describe the specific water content of the wells of groundwater in Chon Buri province, and the aforementioned model can be used to assess the groundwater potential in the province too.

\section{References:}

[1] Noothong, S. (2007) Plot Sampling to Quantify Shallow Groundwater Pumping. Faculty of Agriculture Nature Resources and Environment Naresuan University

[2] Ramingwong, T. (2003). Groundwater. The Department of Geological Sciences, Faculty of Science Chiang Mai University.

[3] Office of the Royal Society. (2001). Dictionary of Geology. Retrieved from

http://library.dmr.go.th/Document/DMR_Tech nical_Reports/References_Thai/2544/10946.pd $\mathrm{f}$

[4] Thaisongkram, V. (2008). The Application of geographic information system to study groundwater resource potential and suitability for development for domestic water supply in Phra Thong Kham district, Nakhon Ratchasima Province, Thailand. Nakhon Ratchasima Rajabhat University, Nakhon Ratchasima province.Retrievedfrom $\mathrm{http}: / /$ newtdc.thailis.or.th/docview.aspx?tdcid= 2458

[5]Ganapuram,,et al. (2009).Mapping of groundwater potential zones in the musi basin using remote sensing data and GIS[J]. Advan. Eng. Soft., 40: 506-518

[6] Hyun-JooOha. (2011). Extraction of landsliderelated factors from ASTER imagery and its application to landslide susceptibility mapping, International Journal of Remote Sensing, Volume 33, Issue 10. DOI: 10.1080/01431161.2010.545084

[7] Thapinta, A., Hudak, P.F. (2000). Pesticide Use and Residual Occurrence in Thailand, Environmental Monitoring and Assessment, Vol 60, pp.103-114.

[8] Rung-uraporn, W. (2000). Application of Geographic Information System for budget allocation in well drilling. Kasetsart University. Bangkok.

[9] Puangkaew, N. (2013). Assessment of water use for agriculture in Phuket province. 
Prince of Songkla University, Phuket CampusRetrieved from http://kb.psu.ac.th/psukb/handle/2010/9238

[10] Wangwongwiroj, N. (2008). Hydrology. Department of Civil Engineering, Faculty of EngineeringKing Mongkut's University of Technology Thonburi.

[11] Department of GroundwaterResources.(2007).

Groundwater Development Technology

Handbook. Retrieved from

http://www2.dgr.go.th/manual.php?=\%E0\%B8 $\% 84 \%$ E0\%B8\%B9\%Е0\%B9\%88\%Е0\%B8\%A $1 \% \mathrm{E} 0 \% \mathrm{~B} 8 \% \mathrm{~B} 7 \% \mathrm{E} 0 \% \mathrm{~B} 8 \% \mathrm{AD}$

[12] Udomsilpa, P. (2004)." A Spatial Modeling for Ground Water Potential Using Geographic Information System: A Case Study in Amphoe Muang, KhonKaen Province. KhonKaen University. Retrieved from http://newtdc.thailis.or.th/docview.aspx?tdcid= 217534

[13] Tassadit Chekari, Rachid Mansouri, Maamar Bettayeb. (2019). Experimental Validation of IMC-PID-FOF Controllers on the Water Level Tank System. WSEAS Transactions on Systems and Control, pp. 460-466, Volume 14

\section{Creative Commons Attribution License 4.0 (Attribution 4.0 International, CC BY 4.0)}

This article is published under the terms of the Creative Commons Attribution License 4.0

https://creativecommons.org/licenses/by/4.0/deed.en_US 